\title{
Kahramanmaraş İl Merkezinde Tüketicilerin Sigara ve Maraş Otu Kullanımını Etkileyen Faktörlerin Analizi
}

\author{
Cuma AKBAY \\ Ali KAFAS \\ Kahramanmaraş Sütçü İmam Üniversitesi, Ziraat Fakültesi, Tarım Ekonomisi Bölümü, Kahramanmaraş \\ : cakbay@ksu.edu.tr
}

Geliş (Received): 05.04.2016

Kabul (Accepted): 14.11.2016

\begin{abstract}
ÖZET: Bu çalışmanın amacı Kahramanmaraş ili şehir merkezinde ikamet eden 18 yaş üstü 400 tüketicinin sigara ve dumansız tütün (maraş otu) kullanımında etkili olan sosyoekonomik ve demografik faktörler, yaşam biçimi ve sağlikla ilgili faktörleri araştırmaktır. Araştırma verileri maraş otu kullanımının oldukça yüksek olduğu Kahramanmaraş merkez ilçede ikamet eden aile bireylerinin sigara ve maraş otu kullanıcılarının sosyoekonomik ve demografik karakteristiklerini içermektedir.

Araştırmada, maraş otu ve sigara kullanım yaygınlığında özellikle yaş ve cinsiyetin önemli etkileri olduğu saptanmıştır. Anket döneminde, erkeklerin bayanlara oranla istatistiksel olarak daha fazla oranda maraş otu kullandığı saptanmıştır (\%25.1 ve \%1.4). Sigara kullanma alışkanlığı da aynı şekilde erkekler arasında bayanlara oranla daha fazla yaygınlık göstermektedir (\%38,6 ve \%22,7). Geçmişte sigara kullanmış olan bireylerin \%71,4’ü ve anket döneminde sigara kullananların ise \%6,8'i maraş otu kullanmışlardır. $\mathrm{Bu}$ fark erkekler arasında ise daha büyüktür $(\% 78,4$ ve $\% 14,0)$.

Araştırma sonuçlarına göre, günlük veya ara sıra sigara kullanımı özellikle erkekler, bekârlar, az eğitimli bireyler ve alkol tüketen bireyler arasında yaygınlık gösterirken, Maraş otu kullanımı düşük gelirli, az eğitimli, yaşlı, erkek veya bekar bireyler arasında yaygınlık göstermektedir. Anket yapılan bireyler arasında, tütün kullanımının özelliklede maraş otu tüketim yaygınlı̆̆ının yüksek olması, bu alışkanlıkların sağlık etkileri konusunda halkın eğitilmesi gerektiğini göstermektedir.
\end{abstract}

Anahtar Kelimeler: Sigara, Maraş otu kullanımı, dumansız tütün, Kahramanmaraş

\section{Analysis of factors Affecting Cigarette Smoking and Maras Powder Use Among Adults in the Urban Area of Kahramanmaraş}

\begin{abstract}
The objective of this study was to investigate how socio-economic and demographic factors, lifestyle and health-related characteristics were associated with the prevalence of cigarette, smokeless tobacco and dual tobacco use among 259 men and 141 women aged 18-70 years in Kahramanmaras. Data were collected about socioeconomic and demographic characteristics of cigarette smoking and use of smokeless tobacco (maras powder) by the family members in Kahramanmaras City center, the population of which has a high prevalence of maras powder use.

Significant differences were found in prevalence of maras powder use and of cigarette smoking by age and gender. A significantly higher proportion of males than females were maras powder users $(25.1 \%$ vs $1.4 \%)$ at the time of the interview. Similarly, cigarette smoking was also significantly higher among males $(38,6 \%$ vs $22,7 \%)$ compared to females. Seventy-one per cent of former smokers and 10,6\% of current smokers had ever used powder. The difference was larger among men ( $78,4 \%$ versus $14 \%)$.

Results indicated that, daily or occasionally smoking was more common among male consumer with single parents, less educated consumer and consumers using alcohol. On the other hand, daily or occasionally maras powder use was more common among lower-income and less educated consumers, elderly people, male consumer with single parents, less educated consumer and consumers using alcohol. In view of the high prevalence of tobacco use, especially of maras powder use, among the population surveyed, there is an urgent need to educate the public on the health consequences of these habits.
\end{abstract}

Keywords: cigarette smoking, maras powder use, smokeless tobacco, Kahramanmaras

\section{GíRiş}

Çağımızın salgını olarak tarif edilen tütün kullanımı; dünyada yılda 5 milyondan fazla kişinin hayatını kaybetmesine neden olmakta ve her on yetişkin ölümünden bir tanesinin sorumlusu tutulmaktadır. Tütün kullanımı en çok ölüm oranını artıran 5 risk faktörü içerisinde önlenebilir tek faktördür. Dünyanın en önde gelen ölüm sebeplerinden olan iskemik kalp hastalığının $\% 11$ 'inden, akciğer, trakea ve bronş kanserlerinin ise $\% 70$ 'inden sorumludur. Mevcut durumla devam edilirse 2030'a kadar her yıl 8 milyondan fazla insanın tütün kullanımından dolayı ölmesi öngörülmekle birlikte dünyada sigara kullanan bir milyar kullanıcinın yarısından fazlası tütüne bağlı hastalıklardan erken ölecektir (WHO, 2011). Bu durum Türkiye için düşünüldüğünde ise, yirmi milyon sigara kullanıcısının yarısının yani on milyon bireyin sigaradan kaynaklı hastalıklardan dolayı önümüzdeki 30 ila 40 yıl içerisinde öleceği belirtilmektedir (Bilir, 2009). 
Diğer taraftan tütün kullanımı maliyeti de eşit ölçüde yıkıcıdır. Bu durum, tütünden kaynaklanan hastalıklarla mücadele için yüksek sağlık harcamalarına sebebiyet vermekte, tütün kullanımından ötürü hastalanan kimselerde verim düşüklüğüne neden olmakta ve erken ölümlerden dolayı bu kimselerin aileleri ihtiyaç duydukları gelirden mahrum kalmaktadır (WHO, 2011). Tütün kullanımının ekonomideki bu yıkıcı etkisi ve boşa giden sermaye kolayca izah edilebilir. Sigara kullanımı için heba edilen paranın toplamı milyarlarla ifade edilecek kadar yüksek bir meblağdır. Türkiye'de sigara bağımlılarının sadece sigara temin etmek için sarf ettikleri maliyetin 1/4’ü, Sağlık Bakanlığı bütçesinin tamamına eşittir. Diğer taraftan sigara bağımlılarının sigara kaynaklı sağlık problemlerinin teşhis ve tedavisi için yapılacak harcamalar da göz önünde bulundurulduğunda, tütün kullanımı için toplum ve bireylerin ne kadar büyük bir ekonomik değerden vazgeçtikleri ve bu değeri heba ettiği anlaşılabilir. Oysaki bu ekonomik değer insanların eğitim, gıda, giyim, sağlık gibi temel ihtiyaçlara harcanarak refah seviyelerinin yükselmesine katkıda bulunabilir. Bununla birlikte sigara alışkanlığ için ödenen değer bireye hiçbir katkıda bulunmamaktadır (Bilir, 2009).

Tütün kullanımıyla yoksulluk ayrılmaz şekilde birbirine bağlıdır. Birçok çalışma düşük ve orta gelirli ülkelerdeki yoksul hanelerdeki toplam harcamanın \%10'unun tütün kullanım maliyeti olduğunu göstermektedir. Bunun anlamı bu ailelerin gıda, eğitim ve sağlık gibi temel ihtiyaçlarına daha az bütçe ayırdığıdır. Gıda ve eğitime harcanabilecek paranın tütün kullanımına harcandığı düşünüldüğünde, tütün kullanımının yetersiz beslenme ve cehalet oranlarını olumsuz etkilediği söylenebilir. Dolayısıyla, yoksulluğun artmasında ve ekonomik gelişmenin engellenmesinde tütün kullanımının rolü tam olarak kabullenilmesi gereken bir durumdur (WHO, 2011).

Önder (2011) tarafindan yapılan bir çalışmada, aile reisinin üniversite mezunu olduğu ailelerin sigara kullanma ihtimalinin ilkokul mezunlarına göre daha düşük olduğu ve aile reisinin yönetici sınıfta olanların sigara içme ihtimalinin işçi sınıfında olan aile reislerine göre daha düşük olduğu sonuçları çıkmıştır.

Nitekim bunun için uluslararası ve ulusal birçok kuruluş önlem alıcı çalışmalar yürütmektedir. Bu tütün kontrol önlemleri önemli etkiye sahip olmakla birlikte farklı yöntemlerle yapılmaktadır. Bunlardan başlıcaları; tanıtım, sponsorluk vb. sigara reklamlarının yasaklanması, tütün vergi ve fiyatlarının artırılması, kapalı ve kamu alanlarında sigara kullanımının yasaklanması ve sigara paketlerinin üzerinde net bir şekilde görülebilen sağlık mesajları gibi nüfus üzerinde etkili kamu politikalarıdır (WHO, 2011). Türkiye'de yıllık tütün mamulü (sigara) tüketimi 5,5 milyar paket civarlarındadır. Nüfusu Türkiye nüfusuna benzerlik gösteren ülkelerden İngiltere'nin 3.7 milyar, Almanya'nın 7.1 milyar, Fransa'nın 4 milyar paket civarlarında sigara tükettiği bilinmektedir. Türkiye'de sigara üzerindeki vergi yükü ortalaması (ÖTV+KDV) $\% 73.25$ 'tir. Uluslararası deneyimler tütün mamullerine olan talebin azaltılmasında, tütün mamulleri fiyatının artırılmasının çok etkili olduğunu göstermektedir. Vergi artırımı yolu ile tütün mamullerinin fiyatının artırılması, özellikle gençler ve düşük gelir grupları arasında bu ürünlerin tüketiminde azalmaya yol açmakta, kamu gelirlerinde ise artış sağlamaktadır. Dünya Bankasının verilerine bakıldığında, sigara fiyatlarındaki \%10'luk bir artış tüketimde $\% 4$ oranında gerilemeye neden olmaktadır. Bu durum geliri yüksek ülkelerde $\% 2,5-5$, gelirli orta ve düşük ülkelerde de \%5-10 seviyelerinde gerçekleşmektedir (Anonim, 2008). Buna rağmen geçmişte bazı yerli marka sigaraların maliyetinin altında satılmış olup devletin önemli bir vergi kaybına uğratmıştır (Önder, 2011). Sigaranın bu kadar ucuz olması Türkiye'de sigara kullanım oranlarını yükselteceği, sigara başlama yaşını aşağıya çekeceği öngörülebilir.

Türkiye, sigaranın yüksek oranla tüketildiği ülkelerden biridir. ABD Tarım Bakanlığı verilerine bakıldığında, 1990-1999 seneleri arasında dünyadaki toplam sigara kullanımı \%4,12 eksilmiş, bu durumun aksine aynı zaman diliminde Türkiye'deki sigara kullanımı geçmiş yıllara göre \%52,18 daha fazladır. Bu durum Türkiye'yi, Pakistan ve Bulgaristan'dan sonra sigara tüketiminde dünyada üçüncü sıraya sokmaya yeterli olmuştur. Yetişkin birey başına tüketim 1990 senesinde 86,92 paket iken, bu rakam artış göstererek 2000 senesinde 134,65 paketi bulmuştur. Ayrıca son zamanlarda yerli sigara kullanımı azalmış, yabancı sigara kullanımı ise artmış durumdadır (Önder, 2011). Bunun da ülke ekonomisine fazladan bir yük getirdiği düşünülebilir.

Türkiye'de tütün ürünleriyle mücadele dendiği zaman genel olarak akla ilk gelen sigarayla mücadeledir, oysaki farklı şekildeki tütün kullanımları da sağlığa zararlıdır. Dünyanın çeşitli bölgelerinde yaygın olarak kullanılan tütün kullanımının bir şeklide dumansız tütün kullanımıdır. Dumansız tütün kullanımının dünyada birçok çeşidi olmakla birlikte dumansız tütünün bir çeşidi olan maraş otu Türkiye'nin güneydoğu illerinde özellikle Kahramanmaraş ve çevresinde yaygın olarak sigara yerine kullanılmaktadır. Kullanılan bu toz Nicotiana rustica L. bitkisinin toz haline getirildikten sonra kül ile karıştırılmasından oluşur. Maraş otu alt dudağa konularak bir miktar (4-5 dakika) bekletilerek uygulanır ve daha sonra çıkartılıp atılır. Bu işlem gün içerisinde ihtiyaca göre birkaç kez tekrarlanır (Erenmemişoğlu, 1997). Maraş otuyla benzerlik gösteren çeşitli tütün ürünleri mevcuttur. İsveç ve bazı İskandinav ülkelerinde yaygın olarak kullanılan snus ve Sudanda kullanılan toombak kullanım şekli, raf ömrü ve yapılış şekliyle benzerlikler göstermektedir (Anonim, 2011a).

Dumansız bir tütün formu olan maraş otu sigara gibi insan sağlığına zarar vermesiyle birlikte fiyatı sigara fiyatlarından çok ucuzdur. Maraş otu özellikle denetimin etkin bir şekilde yapılmadığı da düşünüldüğünde alım gücü düşük olan çocukların bu maddeye kolayca ulaşılabileceği göz önünde olup bu konuda yapılmış olan bir çalışmada sigaraya göre kolay 
elde edilebilmesi bu madde (dumansız tütün) kullanımına etki etmektedir (Rozi ve Akhtar, 2007). Nitekim görsel ve yazılı medyada Kahramanmaraş'ta öğrencilerin yaygın olarak maraş otu kullandığ haberleri yer almıştır. Kapalı alanlarda sigara kullanımının yasaklanmasından ötürü dumansız olan maraş otunun kapalı alanlarda fark edilmeden rahatça kullanılabileceği düşünülebilir. Maraş otu satıcılarının tezgâhlarının üzerindeki yazılı tabirler özendirici niteliktedir. Ayrıca halk arasında söylenen bazı tabirler de maraş otu kullanmanın Kahramanmaraşılı olmanın bir gereği gibi ifade edilmektedir (Anonim, 2011b). Maraş otunun sigara kullanımını azatlığ 1 veya bitirdiği ve zararı olmadığ 1 gibi çarpık düşünceler vardır. Nitekim Amerika Birleşik Devletlerinde yapılan bir çalışmada erkek öğrenicilerin neredeyse yarısının dumansız tütünün zararlı olmadığına inandığı ortaya çıkmıştır (Cohen ve ark, 1987). İsviçre'de maraş otuyla benzerlik gösteren snus kullanımıyla alakalı bir çalışmada snus kullanıcıların \%21'inin sigarayı birakmak için, $\% 56,6$ 'sının ise sigaranın insan sağlığına daha fazla zarar verdiği için snus kullanımına başladıkları anlaşılmıştır (Gilljam ve Galanti, 2003).

Sigaranın ve diğer tütün ürünlerinin insan sağlığına verdiği zarar şüphe götürmez bir gerçektir. Bundan dolayıdır ki disiplinler arası bir konu olan sigara ve tütün ürünlerinin kullanımı birçok kez farklı yönleriyle ele alınmış ve ortaya konmuştur. Ancak Kahramanmaraş ili ve çevresinde yaygın olarak kullanılan maraş otu ve sigara içiciliği prevalansını etkileyen sosyoekonomik ve demografik faktörlerin ele alındığı bir çalışmaya yurtiçinde rastlanılmamıştır. Bundan dolayı çalışma ayrı bir önem arz etmekte olup çalışmanın amacı Kahramanmaraş il merkezinde sigara ve maraş otu yaygınlığını saptamak ve sigara ve maraş otunu etkilediği düşünülen faktörleri analiz etmektir.

\section{MATERYAL ve METOT}

$\mathrm{Bu}$ çalışmanın materyali, 2010 yılında Kahramanmaraş ili kentsel alanda ikamet eden ve örnekleme yöntemiyle seçilen bireylerin maraş otu ve sigara kullanımına etki eden faktörleri ve kullanım yaygınlığını tespit etmek amacıyla yüz yüze yapılan anketlerden oluşmuştur. Bu çalışmada örnek hacmi, ana kitle oranlarına dayalı kümelendirilmiş tek aşamalı tesadüfî olasılık örnekleme yöntemi ile belirlenmiştir (Collins, 1986):

$$
n=t^{2} \cdot(p \cdot q) / e^{2}
$$

burada; n: Örnek hacmi; t: \%95 önem derecesine karşılık gelen tablo değeri; p: İncelenen olayın ana kitle içinde gerçekleşme olasılığı (\%50 olarak alınmıştır); q: İncelenen olayın gerçekleşmeme olasılığ (1-p); e: Kabul edilen hata payı (bu çalışmada \%5 olarak alınmıştır). Örnek hacmi, örnekleme dışı hatalar ve kayıp değerler de göz önüne alınarak 384 olarak belirlenmiş olup, bu örnek sayısı 400'e tamamlanmıştır.

Çalışmada, bireylerin sosyoekonomik ve demografik grupları itibariyle sigara ve maraş otu kullanımları araştırılmıştır. Maraş otu ve sigara kullanımıyla ilgili değişkenler arasındaki ilişkilerin istatistiksel olarak anlamlılığının test edilmesinde Ki-kare bağımsızlık testi kullanılmıştır.

\section{BULGULAR ve TARTIŞMA}

$\mathrm{Bu}$ çalışmada anket yapılan 400 katılımcının $\% 64,8$ 'ini erkek, $\% 76,5$ 'sin 1 ise evli bireyler oluşturmaktadır. Ankete katılan bireylerin \%7'si okuryazar ve alt1, \%17,8'i ilkokul mezunu, 16,2'si ortaokul mezunu, \%37,5'i lise mezunu ve \%21,5'inin üniversite mezunu olduğu saptanmıştır. Anket sonuçlara göre, katılımcıların; \% 22,8'i 18-25 yaş aralığında, \%38,7'si 26-35 yaş aralığında, \%23,0'1 36-45 yaş aralığında ve \%15,5'i 46 yaş ve üstündeki bireylerden oluşmaktadır.

Sosyo-demografik gruplar itibariyle bireylerin sigara, maraş otu ve tütün kullanım durumları Çizelge 1, 2 ve 3'de verilmiştir. Anket sonuçlarına göre, bireylerin yaklaşık \%67'si sigara kullanırken, \%33'ü ise kullanmamaktadır (Çizelge 1). Hane halkı geliri, eğitim, yaş, cinsiyet, medeni durum, maraş otu kullanma durumu ve alkol tüketme durumunun sigara tüketimi üzerinde istatistikî olarak önemli bir etkisi olduğu görülmektedir. Sonuçlara göre, erkeklerin sigara kullanma oranı kadınlardan \%15,9 daha fazladır. Sigara kullanım oranı erkeklerde 2006 yılı Türkiye ortalamasından $(\% 50,6)$ düşük çıkmıştır (TÜİK, 2006). $\mathrm{Bu}$ durum tütün kullanımıyla ilişkili çıkan yeni yasalar ve artan sigara fiyatlarına bağlanabilir. Ancak benzer bir durum İskadinav ülkelerinde söz konusudur. Özellikle İsveç'te kullanılan bir dumansız tütün formu olan snus, maraş otuyla büyük benzerlikler içermektedir. 1986 yılında 25-64 yaş arası İsveç erkeklerinin \%22'si snus, \%19'u sigara kullanmakta iken 1999 yılında erkeklerin \%30'u snus, \%11'i sigara kullanır hale gelmişlerdir (Rodu ve ark, 2002).

Sigara tüketim olasılığı ile gelir düzeyi arasında istatistikî olarak önemli bir ilişki olduğu saptanmıştır. Yüksek gelir grubunda bulunan bireyler düşük ve orta gelir grubunda olanlara oranla daha az sigara kullandıkları saptanmıştır. Düşük gelir grubundaki bireylerin \%33,9'u, orta gelir grubundaki bireylerin $\% 19,6$ 's1 ve yüksek gelir grubundaki bireylerin ise $\% 48,8$ 'i günlük sigara kullanıcısıdır. Gelir durumu itibariyle bireylerde günlük sigara kullanıcısı olma durumu farklılık arz etmekle birlikte düzensiz bir değişim göstermiştir.

Özellikle eğitim düzeyinin sigara kullanımı üzerinde önemli bir etkisinin olduğu görülmektedir. Bireylerin eğitim düzeyleri artıkça sigara kullanım prevelansı artmaktadır. Okuryazar veya ilkokul mezunu olanlarda sigara kullanım oranı \%15.9 iken üniversite mezunu olan bireylerde bu oran \%48.8'e yükselmiştir. Bu oranların arası kadın bireylerde daha da açılarak üniversite mezunu kadın bireylerin \%60'nın sigara kullandığı ortaya çıkmıştır. Bu oran yüksek bulunabilir ancak yapılan bir araştırmada bir kamu kurumunda çalışan erkek personelin \%44,1'i, kadın personelin ise \%55,9'nun sigara kullandığı tespit edilmiştir (Altıntaş ve ark. 2006). Bu bilgi, üniversite mezunu kadın bireylerin birçoğunun çalıştığı varsayımı ile birlikte 
düşünüldüğünde çıkan sonuç daha iyi yorumlanabilir.

Katılımcılardan yüksek yaş gruplarında sigara kullanım oranı düşük bulunurken daha genç bireylerde yüksek bulunmuştur. $46+$ yaş grubunda günlük sigara kullanıcıları \%14,5 iken bu oran 18-25 yaş arası bireylerde \%37,4 çıkmıştır. Sigara ve maraş otu kullanımı, hem erkek bireyler hem kadın bireyler arasında medeni duruma göre farklılık arz etmektedir. Bekâr bireylerin \%46,8'i sigara kullanırken evli bireylerin \%28,8'i kullanmaktadır. Asla alkol kullanmam diyenlerin \%19'unun sigara kullandığ 1 , düzenli olarak alkol kullanıyorum diyenlerin \%88,9'unun sigara kullandığı tespit edilmiştir.

Diğer taraftan hanehalkı gelir, eğitim, yaş, cinsiyet, medeni durum ve sigara kullanma durumunun maraş otu tüketimi üzerinde istatistikî olarak önemli bir etkisi olduğu görülmektedir (Çizelge 2). Anket sonuçlarına göre, bireylerin yaklaşık \%16,7'si maraş otu kullanırken, \%83,3’ü ise kullanmamaktadır. Maraş otu kullanma olasılığı ile gelir düzeyi arasında istatistikî olarak önemli bir ilişki olduğu saptanmıştır. Yüksek gelir grubunda bulunan bireylerin \%3,1'i maraş otu kullanırken, bu oran artış göstererek orta gelir grubunda $\% 22,2$ düşük gelir grubunda ise $\% 24,3$ bulunmuştur.

Araştırma sonuçları, eğitim düzeyine göre maraş otu kullanmada farklılık arz etmekte olup yapılan çalışmada eğitim grupları itibariyle \%95 güven aralığında istatistiksel olarak anlamlı farklılıklar olduğunu göstermiştir. Katılımcıların maraş otunu kullanmama durumu \%95,3'lük bir oranla üniversite mezunları arasında en fazla yaygınlık göstermiş olup eğitim düzeyi ile birlikte azalan bir eğilim göstermektedir. İlkokul ve altı grubundaki bireylerin maraş otu kullanma olasıllığı diğer iki gruba göre yüksek bulunmuştur. Bu sonuç Rodu ve ark. (2002) tarafindan yapılan çalışmayla uyum göstermektedir. Genel olarak yaş artıkça günlük kullanıcı olma durumu oransal olarak artma eğiliminde olmakla birlikte tüketmeme durumu oransal olarak azalma eğilimindedir. Diğer taraftan erkeklerin \%25,1'inin ve kadınların \%1,4'ünün maraş otu kullandığı ve aralarındaki farkın \%23,7 ile sigara kullanım farkından daha yüksek çıktığı tespit edilmiştir. Maraş otuna kadınların rağbet etmediği görülmektedir.

Özellikle sigara kullanmanın maraş otu kullanma üzerinde etkili olduğu düşünülmektedir. Araştırma sonuçları sigara kullanmamanın maraş otu kullanma olasılığını artırdığı görülmektedir. Yapılan çapraz tablolara göre geçmişte sigara kullanıcılarının \%71,4'ü, ara sıra kullanıyorum diyenlerin \%55,6'sı günlük maraş otu kullanıcısı olduğu anlaşılmışıtır. Maraş otuyla benzerlik gösteren snus kullanımın sigarayı azaltmada ne kadar etkili olduğunun araştırıldığı bir çalışmada snus kullanıcıların \%33'nün geçmişte sigara kullandığı, \%27'sinin de halen kullanmaya devam ettiği anlaşılmıştır (Gillljam ve Galanti, 2003). Aynı şekilde
Lund çalışmasında belirttiği üzere snus kullanıcılarının birçoğunun sigara deneyimi olduğunu belirtmiştir (Lund ve ark, 2011). Sigara kullanma durumu, alkol kullanımıyla istatistiki olarak anlamlı bulunmuş olmasına rağmen maraş otu kullanımı yapılan khi-kare testine göre alkol kullanımıyla alakalı bulunmamıştır.

Anket yapılan bireylerin yaşları itibariyle maraş otu kullanımı arasında istatistiki olarak bir fark olduğu tespit edilmiştir. Maraş otu kullanımı, 46+ yaş grubunda $\% 38,7$ iken $18-25$ yaş bireylerde bu oran $\% 2,2$ olarak bulunmuştur. Buradan anlaşılacağı üzere genç bireyler sigara kullanımına yönelirken yaş artışına bağlı olarak oransal olarak düşüş olmakta ve maraş otu kullanımına yönelmektedirler. Nitekim sigara vb. bağımlılık yapıcı maddeleri kullanan kimselerin tatmin düzeyini sağlamak için sürekli madde alımını artırmak eğiliminde oldukları bilinmektedir (Anonim, 2011c). Bunun yanı sıra maraş otunun ham maddesi olan Nicotiana rustica L. sigaranın hammaddesi olan Nicotiana tabacum'dan dan 6-10 kat arası daha fazla nikotin içermektedir (Saitoh ve ark, 1985). Bu bilgiler 1şığında düşünüldüğünde; sigara kullanan genç yaştaki bireylerin zaman içerisinde tatmin düzeyini artırmak için maraş otu kullanımına yönelmeleri muhtemeldir.

Yapılan bir çalışmada toombak kullanımı oranları yaşla birlikte artış göstermektedir. Söz konusu çalışmadan anlaşılacağı üzere 30 yaş ve altında toombak kullanımı \%30'un altında iken 40 yaş ve üzerinde kullanım oranı \%40'ın üzerindedir (Idris ve ark, 1998). Çalışmada çıkan sonuçların bizim çalışmamızda çıkan sonuçlarla benzerlik arz etmektedir. Ayrıca yapılan farklı bir çalışmada yetişkin Nijerya popülasyonunda erkeklerde 50-60 yaş arası olmanın dumansız tütün kullanımında belirleyici bir rol oynadığı tespit edilmiştir (Desalu ve ark, 2010).

Maraş otu kullanımında, bekâr bireylerin $\% 6,4$ 'ünün, evli bireylerin \%19,9'unun günlük maraş otu kullanıcısı olduğu tespit edilmiştir. $\mathrm{Bu}$ oran evli erkeklerde \%30,3 olarak tespit edilmiştir. Buradan anlaşılacağ1 üzere sigara bekâr bireyler arasında yaygınken, maraş otu evli bireyler arasında yangındır. Bu durumun, evli ve bekâr bireylerin yaş ortalamaları ile alakalı olması ihtimal dâhilindedir. Nitekim Rodu ve ark. (2002)'nın çalışmasında evli bireylerin \%57'sinin snus öyküsü varken bekâr bireylerin \%64'nün snus öyküsü olduğu anlaşılmıştır (Rodu ve ark, 2002).

Genel tütün kullanım durumlarına bakıldığında gelir, cinsiyet ve alkol kullanma durumlarının istatistikî olarak tütün kullanma durumuyla anlamlı olduğu izlenmektedir. Erkek bireylerin \%60,2'si her iki üründen birini kullanırken kadın bireylerin \%24,1 tütün ürünleri kullandıklarını ifade ettikleri anlaşılmıştır (Çizelge 3). Toplam tütün kullanımında yaş, eğitim ve medeni durumları istatistiki olarak anlamlı bulunmamıştır. 
Çizelge 1. Demografik gruplar ve diğer değişkenler itibariyle sigara kullanımı (\%)

\begin{tabular}{|c|c|c|c|}
\hline Sosyoekonomik ve demografik gruplar & Kullanmayan & Kullanan & $\begin{array}{l}\text { Khi-Kare testi } \\
\text { (P değeri) }\end{array}$ \\
\hline Sigara Kullanımı & 67.0 & 33.0 & \\
\hline \multicolumn{4}{|l|}{ Gelir grupları } \\
\hline I. Gelir grubu (düşük gelir grubu) & 66.1 & 33.9 & \multirow{3}{*}{$\begin{array}{c}27,21 \\
(0,000)\end{array}$} \\
\hline 2. Gelir grubu (orta gelir grubu) & 80.4 & 19.6 & \\
\hline 3.Gelir grubu (yüksek gelir grubu) & 51.2 & 48.8 & \\
\hline \multicolumn{4}{|l|}{ Tüketicilerin eğitim düzeyi } \\
\hline Okuryazar veya ilkokul mezunu & 84.1 & 15.9 & \multirow{3}{*}{$\begin{array}{c}37,90 \\
(0,000)\end{array}$} \\
\hline Lise mezunu & 57.3 & 42.7 & \\
\hline Üniversite mezunu & 51.2 & 48.8 & \\
\hline \multicolumn{4}{|l|}{ Tüketicilerin yaş grupları } \\
\hline$\leq 25$ & 62.6 & 37.4 & \multirow{4}{*}{$\begin{array}{c}24,94 \\
(0,000)\end{array}$} \\
\hline $26-35$ & 55.5 & 44.5 & \\
\hline $36-45$ & 78.3 & 21.7 & \\
\hline $46+$ & 85.5 & 14.5 & \\
\hline \multicolumn{4}{|l|}{ Tüketicilerin medeni durumu } \\
\hline Bekâr & 53.2 & 46.8 & \multirow{2}{*}{$\begin{array}{c}10,60 \\
(0,001)\end{array}$} \\
\hline Evli & 71.2 & 28.8 & \\
\hline \multicolumn{4}{|l|}{ Tüketicilerin cinsiyeti } \\
\hline Erkek & 61.4 & 38.6 & \multirow{2}{*}{$\begin{array}{c}10,46 \\
(0,000)\end{array}$} \\
\hline Kadın & 77.3 & 22.7 & \\
\hline \multicolumn{4}{|l|}{ Maraş otu kullanma durumu } \\
\hline Hayır & 63.1 & 36.9 & \multirow{2}{*}{$\begin{array}{c}13,94 \\
(0,000)\end{array}$} \\
\hline Evet & 86.6 & 13.4 & \\
\hline \multicolumn{4}{|l|}{ Alkol kullanma durumu } \\
\hline Hayır & 72.7 & 27.3 & \multirow{2}{*}{$\begin{array}{c}39,35 \\
(0,000) \\
\end{array}$} \\
\hline Evet & 28.8 & 71.2 & \\
\hline
\end{tabular}

Çizelge 2. Demografik gruplar ve diğer değişkenler itibariyle Maraş otu kullanımı (\%)

\begin{tabular}{|c|c|c|c|}
\hline Sosyoekonomik ve demografik gruplar & Kullanmayan & Kullanan & $\begin{array}{l}\text { Khi-Kare testi } \\
\text { (P değeri) }\end{array}$ \\
\hline Maraş Otu Kullanımı & 83,3 & 16,7 & \\
\hline \multicolumn{4}{|l|}{ Gelir grupları } \\
\hline I. Gelir grubu (düşük gelir grubu) & 75.7 & 24.3 & \multirow{3}{*}{$\begin{array}{c}24,91 \\
(0,000)\end{array}$} \\
\hline 2. Gelir grubu (orta gelir grubu) & 77.8 & 22.2 & \\
\hline 3.Gelir grubu (yüksek gelir grubu) & 96.9 & 3.1 & \\
\hline \multicolumn{4}{|l|}{ Tüketicilerin eğitim düzeyi } \\
\hline Okuryazar veya ilkokul mezunu & 68.9 & 31.1 & \multirow{3}{*}{$\begin{array}{c}41,47 \\
(0,000)\end{array}$} \\
\hline Lise mezunu & 92.0 & 8.0 & \\
\hline Üniversite mezunu & 95.3 & 4.7 & \\
\hline \multicolumn{4}{|l|}{ Tüketicilerin yaş grupları } \\
\hline$\leq 25$ & 97.8 & 2.2 & \multirow{4}{*}{$\begin{array}{c}44,73 \\
(0,000)\end{array}$} \\
\hline $26-35$ & 89.0 & 11.0 & \\
\hline $36-45$ & 73.9 & 26.1 & \\
\hline $46+$ & 61.3 & 38.7 & \\
\hline \multicolumn{4}{|l|}{ Tüketicilerin medeni durumu } \\
\hline Bekâr & 93.6 & 6.4 & \multirow{2}{*}{$\begin{array}{c}9,47 \\
(0,001)\end{array}$} \\
\hline Evli & 80.1 & 19.9 & \\
\hline \multicolumn{4}{|l|}{ Tüketicilerin cinsiyeti } \\
\hline Erkek & 74.9 & 25.1 & \multirow{2}{*}{$\begin{array}{c}36,71 \\
(0,000) \\
\end{array}$} \\
\hline Kadın & 98.6 & 1.4 & \\
\hline \multicolumn{4}{|l|}{ Sigara kullanma durumu } \\
\hline Hayır & 78.4 & 21.6 & \multirow{2}{*}{$\begin{array}{c}13,94 \\
(0,000)\end{array}$} \\
\hline Evet & 93.2 & 6.8 & \\
\hline \multicolumn{4}{|l|}{ Alkol kullanma durumu } \\
\hline Hayır & 83.0 & 17.0 & \multirow{2}{*}{$\begin{array}{c}0,08 \\
(0,777)\end{array}$} \\
\hline Evet & 84.6 & 15.4 & \\
\hline
\end{tabular}


Çizelge 3. Demografik gruplar ve diğer değişkenler itibariyle Tütün kullanımı (\%)

\begin{tabular}{|c|c|c|c|}
\hline Sosyoekonomik ve demografik gruplar & Kullanmayan & Kullanan & $\begin{array}{l}\text { Khi-Kare testi } \\
\text { (P değeri) }\end{array}$ \\
\hline Tütün Kullanımı & 52,5 & 47,5 & \\
\hline \multicolumn{4}{|l|}{ Gelir grupları } \\
\hline I. Gelir grubu (düşük gelir grubu) & 46.09 & 53.91 & \multirow{3}{*}{$\begin{array}{c}6,272 \\
(0,000)\end{array}$} \\
\hline 2. Gelir grubu (orta gelir grubu) & 60.13 & 39.87 & \\
\hline 3.Gelir grubu (yüksek gelir grubu) & 48.82 & 51.18 & \\
\hline \multicolumn{4}{|l|}{ Tüketicilerin eğitim düzeyi } \\
\hline Okuryazar veya ilkokul mezunu & 56.10 & 43.90 & \multirow{3}{*}{$\begin{array}{c}2,10 \\
(0,349)\end{array}$} \\
\hline Lise mezunu & 52.00 & 48.00 & \\
\hline Üniversite mezunu & 46.51 & 53.49 & \\
\hline \multicolumn{4}{|l|}{ Tüketicilerin yaş grupları } \\
\hline$\leq 25$ & 61.54 & 38.46 & \multirow{4}{*}{$\begin{array}{c}5,40 \\
(0,145)\end{array}$} \\
\hline $26-35$ & 46.45 & 53.55 & \\
\hline $36-45$ & 54.35 & 45.65 & \\
\hline $46+$ & 51.61 & 48.39 & \\
\hline \multicolumn{4}{|l|}{ Tüketicilerin medeni durumu } \\
\hline Bekâr & 50.00 & 50.00 & \multirow{2}{*}{$\begin{array}{c}0,308 \\
(0,579)\end{array}$} \\
\hline Evli & 53.27 & 46.73 & \\
\hline \multicolumn{4}{|l|}{ Tüketicilerin cinsiyeti } \\
\hline Erkek & 39.8 & 60.2 & \multirow{2}{*}{$\begin{array}{c}47,76 \\
(0,000)\end{array}$} \\
\hline Kadın & 75.9 & 24.1 & \\
\hline \multicolumn{4}{|l|}{ Alkol kullanma durumu } \\
\hline Hayır & 56.90 & 43.10 & \multirow{2}{*}{$\begin{array}{c}20,75 \\
(0,000)\end{array}$} \\
\hline Evet & 23.08 & 76.92 & \\
\hline
\end{tabular}

\section{SONUÇ ve TARTIŞMALAR}

Bu çalışmada, Kahramanmaraş ili merkez ilçesinde yaşayan bireylerin maraş otu ve sigara kullanımını etkileyen sosyoekonomik faktörler araştırılmıştır. $\mathrm{Bu}$ amaca yönelik yapılan anket çalışması sonucunda elde edilen bulgulara göre bireylerin \%33'nün sigara kullandığ TÜIKK hane halk1 araştırmasında yer alan \%33,4'e çok yakın çıkmışır (TÜiK, 2006). Ayrıca bireylerin $\% 16,8$ 'nin maraş otu ve $\% 3$ 'nün her iki maddeyi de kullandığı ortaya çıkmıştır.

Sonuçlara göre, erkeklerin sigara kullanma oranı kadınlardan \%15,9 daha fazladır. Diğer taraftan erkeklerin $\% 25,1$ 'inin ve kadınların \%1,4'ünün maraş otu kullandığı ve aralarındaki farkın \%23,7 ile sigara kullanım farkından daha yüksek çıktığı tespit edilmiştir. Bireylerin eğitim düzeyleri artıkça sigara kullanım prevelansı artmaktadır. Okur yazar ve altı eğitim düzeyinde bireylerin \%3,6's1 sigara kullanmakta iken üniversite mezunu olan grubun $\% 48,8$ 'i sigara kullanmaktadır. Diğer taraftan maraş otu kullanan bireyler, okuryazar ve altı grubun \%39,3'ünü oluştururken üniversite mezunu bireylerin \%4,7'sini oluşturmaktadır.

Katılımcılardan yüksek yaş gruplarında sigara kullanım oranı düşük bulunurken daha genç bireylerde yüksek bulunmuştur. $46+$ yaş grubunda günlük sigara kullanıcıları \%14,5 iken bu oran 18-25 yaş arası bireylerde \%37,4 çıkmıştır. Bu durum maraş otu kullanımında tam tersine dönmektedir. Erkek bireyler için, 46+ yaş grubunda maraş otu kullanımı \%38,7 iken $18-25$ yaş bireylerde bu oran $\% 2,2$ olarak bulunmuştur.

Düşük gelir grubundaki bireylerin \%33,9'u, orta gelir grubundaki bireylerin \%19,6's1 ve yüksek gelir grubundaki bireylerin ise $\% 48,8$ ' $i$ günlük sigara kullanıcısıdır. Gelir durumu itibariyle bireylerde günlük sigara kullanıcısı olma durumu farklılık arz etmekle birlikte düzensiz bir değişim göstermiştir. Ancak erkek bireylerin gelir grupları itibariyle maraş otu günlük kullanıcı olma durumuna bakıldığında; düşük gelir grubundaki bireylerin \%33,8'nin, orta gelir grubundaki bireylerin \%31,5'inin ve yüksek gelir grubundaki bireylerin ise \%5,6'sının günlük kullanıcı olduğu anlaşılmıştır.

Alkol kullanan bireylerde sigara kullanımı yaygınken maraş otu kullanımı yaygın değildir. Asla alkol kullanmam diyenlerin \%19'unun sigara kullandığı, düzenli olarak alkol kullanıyorum diyenlerin $\% 88,9$ 'unun sigara kullandığı tespit edilmiştir. Asla alkol kullanmam diyenlerin \%19,7'si maraş otu kullanırken bu oran nadiren alkol kullanıyorum diyenlerde $\% 18,6$ olarak çıkmıştır.

Sigarayla mücadelenin sürdüğü günümüzde olumlu neticeler alınmaktadır. Ancak bölgesel olarak kullanılan maraş otuyla mücadele konusunda aynı şeyi söylemek güç olacaktır. Bir an önce maraş otunun zararları hakkında popülasyon bilgilendirilmelidir. Sigaranın zararsız bir alternatifi gibi algılanılmasının önüne geçilmelidir. Ayrıca maraş otu kayıt dışı olarak üretilmekte ve pazarlanmaktadır. Bundan dolayı sigaradan çok ucuzdur. Ucuzluğu dolayısıyla rağbet görmektedir. $\mathrm{Bu}$ kayıt dışıllğın önüne geçilmeli vergilendirilmelidir. Aksi takdirde sigaraya getirilen her yasak ve maliyet maraş otu kullanımında karşılı̆̆ını bulacaktır.

Çalışma kentsel alanda yürütülmüş olup kırsal alan kapsam dışı bırakılmıştır. Ancak maraş otu kullanımının kırsal alanda daha yaygın olarak kullanıldığı 
öngörülmektedir. Binaenaleyh sonraki çalışmaların kentsel ve kırsal bölgeleri içine alacak şekilde yürütülmesinde gerek karşılaştırmalar açısından, gerek politik kararlar açısından faydalı olacağı düşünülmektedir.

Politik karar alıcıların, ilgili kamu kuruluşlarının ve ilgili tüm organizasyonların konunun önemini anlamaları gerekmekte olup konu yerel bir durumdayken olası bir maraş otu kullanımı artışının önüne geçilerek gelecek nesiller korunmalıdır.

\section{KAYNAKLAR}

Altıntaş H, Boztaş G, Polat C, Salor C, Yaman İ, Uğurlu, E 2006. Bir Kamu Kuruluşu Bilgi İşlem Merkezi Çalışanlarının Sigara İçme İle İlgili Tutum ve Davranışları. Bağımlılık Dergisi, 7 (1): 3-10.

Anonim 2008. Ulusal Tütün Kontrol ve Eylem Planı (2008-2012). T.C. Sağlık Bakanlığı, Ankara. 17s

Anonim 2011a. Dumansız Tütün Çeşitleri. "http://buysnus.be/" (Erișim Tarihi:15.07.2011)

Anonim 2011b. "Maraşlı Öğrenciler Maraş Otu Bağımlısı Çıktı" Başlıklı Haber "www.haberler.com" (Erişim Tarihi: 29.05.2011)

Anonim 2011c. Bağımlılık Süreci Nasıl İşler. "http://www.madde.gov.tr" (Erişim Tarihi: 29.05.2011)

Bilir N 2009. Türkiye Tütün Kontrolünün Neresinde?. Toraks Dergisi, 10 (1): 31-34

Cohen RT, Sattler J, Felix MRJ, Brownell KD 1987. Experimentation with Smokeless Tobacco and Cigarettes by Children and Adolescents: Relationship to Beliefs, Peer Use, and Parental Use. American Journal of Public Health, 77(11): 14541456

Collins M 1986, Sampling (Editör: R.Worcester ve ark. 1986), Consumer Market Research Handbook.
Desalu OO, Isheh KR, Olakoba AB, Salawu FK, Danburam A 2010. Smokeless Tobacco Use in Adult Nigerian Population. Nigerian Journal of Clinical Practice, 13(4).382-387

Erenmemişoğlu A 1999. Turkish Smokeless Tobacco "Maraş Powder". Prev Med 28(6): 616-617

Gilljam H, Galanti MR 2003. Role of Snus (oral moist snuff) in Smoking Cessation and Smoking Reduction in Sweden. Addiction, 98 (9):1183-1189

Idris AM, Ibrahim YE, Warnakulasuriya KAAS, Cooper DJ, Johnson NW, Nilsen R, Odont B 1998. Toombak Use and Cigarette Smoking in the Sudan: Estimates of Prevalence in the Nile State. Prevemtive Medecine 27(4): 597-603

Lund EK, Scheffels J, McNeill A 2011. The Association Between Use of Snus and Quit Rates for Smoking: Result from Seven Norwegian Cross-sectional Studies. Addiction, 106 (1): 162-167

Önder Z 2011. Türkiye'de Sigara Fiyatları ve Tüketim İlişkisi. "www.toraks.org.tr/userfiles/file /Tr\%20sigar_fiyatlari-zeynep_onder.pdf”

Rodu B, Stegmayr B, Nasic S, Asplund K 2002. Impact of smokeless Tobacco Use on Smoking in Northern Sweden. Journal of Internal Medicine , 252 (5): 398-404

Rozi S, Akhtar S 2007. Prevalence and Predictors of Smokeless Tobacco Use Among High-School Males in Karachi, Pakistan. Eastern Mediterranean Health Journal, 13 (4): 916-924

Saitoh F, Noma M, Kawashima N 1985. The Alkaloid Contents of Sixty Nicotiana Species. Phytochemistry, 24:477-480.

TÜİK 2006. Aile Yapısı Araştırması. "www.tuik.gov.tr." (Erişim Tarihi: 15.06.2011)

WHO 2011. Why tobacco is a puplic health priority, "http:// www.who.int/tobacco /health_priority/en/" 